\title{
Kemampuan Numerik Siswa Kelas VIII SMP Negeri 6 Kendari Ditinjau Dari Perbedaan Jenis Kelamin Dan Disposisi Matematika
}

\author{
(Numerical Ability Of Grade VIII Students Of SMP Negeri 6 Kendari In Terms Of Gender \\ Differences And Mathematical Disposition)
}

\author{
Wa Ode Haliana ${ }^{1}$, Kadir $^{2}, K_{\text {odirun }}^{2}$, Saleh $^{3}$ \\ ${ }^{1}$ Alumnus Jurusan Pendidikan Matematika FKIP Universitas Halu Oleo \\ ${ }^{2}$ Dosen Pendidikan Matematika FKIP dan PPs Universitas Halu Oleo \\ ${ }^{3}$ Dosen Pendidikan Matematika FKIP Universitas Halu Oleo; Co-author: saleh0377@gmail.com
}

\begin{abstract}
Abstrak: Penelitian ini bertujuan untuk 1) Mendeskripsikan kemampuan numerik siswa laki-laki dan perempuan pesisir, 2) Mendeskripsikan kemampuan numerik siswa di pesisir dengan disposisi matematika tinggi, 3) Mendeskripsikan kemampuan numerik siswa pesisir dengan disposisi matematika sedang, 4) Mendeskripsikan kemampuan numerik siswa pesisir dengan disposisi matematika rendah dan 5) Mendeskripsikan disposisi matematika siswa pesisir. Populasi dalam penelitian ini yaitu semua siswa kelas VIII SMP Negeri 6 Kendari . Jenis penelitian ini adalah penelitian deskriptif eksploratif. Hasil penelitian menunjukkan bahwa 1) Kemampuan numerik siswa laki-laki dan perempuan sudah baik tetapi dari ketiga jenis soal siswa masih lemah pada hitung-menghitung, 2) Kemampuan numerik siswa dengan disposisi matematika tinggi sangat baik, 3) Kemampuan numerik siswa dengan disposisi matematika sedang sudah baik, 4) Kemampuan numerik siswa laki-laki kategori rendah dan disposisi matematika siswa laki-laki kategori rendah hanya 1 siswa dan 5) Disposisi matematika siswa laki-laki dan perempuan lemah pada ketertarikan, keingintahuan, dan kemampuan untuk menemukan dalam mengerjakan matematika.
\end{abstract}

Kata kunci: Kemampuan Numerik, Disposisi Matematika, Jenis Kelamin

\begin{abstract}
This study aims to 1) Describe the numerical abilities of male and coastal students, 2) Describe the numerical abilities of students in coanstal areas with high mathematical disposition, 3) Describe the numerical abilities of coastal students with moderate mathematical dispositions, 4) Describe the numerical abilities of coastal students with low mathematical disposition and 5) Describe the mathematical disposition of coastal students. The population in this study is all eighth grade students of SMP Negeri 6 Kendari. This type of research is explorative descriptive research. The results showed that 1) The numerical ability of male and female students was good but of the three types of questions students were still weak in counting, 2) The numerical ability of students with high mathematical disposition was very good, 3) The numerical ability of students with moderate mathematical dispositions already good, 4) Low numerical ability of male students and low disposition of male students in only one student and 5) Mathematical disposition of male aand female students is weak in interenst, curiosity, and ability of find mathematical.
\end{abstract}

Keywords: Numerical Ability, Mathematical Disposition, Gender

\section{PENDAHULUAN}

Pendidikan matematika di Indonesia berkembang sejalan dengan perkembangan pendidikan matematika di dunia. Perubahan-perubahan yang terjadi dalam proses pembelajaran di kelas, selain dipengaruhi adanya ilmu pengetahuan siswa juga dituntut untuk dapat memanfaatkan perkembangan teknologi. Hal ini dapat dipahami sebab perubahan yang terjadi dalam proses pembelajaran matematika tidak terlepas dari adanya perubahan pandangan tentang belajar matematika.

Mulyasa (2006 : 2) mengungkapkan pendidikan merupakan suatu kebutuhan yang harus dipenuhi dengan bermasyarakat, berbangsa, dan bernegara. Majunya suatu bangsa banyak ditentukan oleh kreatifitas pendidikan bangsa itu sendiri, karena pendidikan sebagai upaya mencetak sumber daya manusia yang berkualitas dan berdedikasi tinggi. 
UNESCO berpandangan bahwa siswa SMP Perlu disiapkan sejak dini agar perubahan fisiologis dan psikologis mereka berdampak positif pada tata cara mereka mengakses pelajaran dan memiliki perilaku serta gaya hidup yang diperlukan untuk menyiapkan dan memperoleh masa depan yang lebih baik sedangkan permasalahan lain pesisir sebagian besar siswa dilibatkan oleh orang tua guna mencari nafkah untuk membantu kebutuhan hidup sehari-hari padahal kita tahu bahwa pendidikan sangat penting pada usia dini.

Tujuan penbelajaran matematika dapat terwujud jika siswa memiliki kemampuan numerik. Dalam kurikulum KTSP 2006 disebutkan lima kemampuan matematika diantaranya adalah pemahaman konsep, penalaran, komunikasi, pemecahan masalah, dan representasi matematika. Dari uraian tersebut jelas bahwa kemampuan numerik dan sikap positif (disposisi) antara jenis kelamin di pesisir terhadap matematika merupakan bagian kopetensi yang harus dicapai dalam pembelajaran matematika.

Matematika akan lebih mudah dipelajari oleh orang-orang yang mempunyai kemampuan numerik. Kemampuan numerik merupakan kemampuan khusus dalam ilmu berhitung. Menurut O'Donoghue (2007 : 53), numerik tidak boleh disamakan dengan kurangnya sekolah matematika dan ini tidak hanya tentang keterampilan berhitung. Sebaliknya, numerik adalah tentang kemampuan mengolah, mengaplikasikan, dan pengambilan kesimpulan dengan angka-angka. Numerik memiliki dampak besar pada setiap orang diseluruh kelompok umur dalam pendidikan mereka di sekolah maupun diluar pendidikan formal. Lebih lanjut dan bahkan lebih menarik, karena berdasarkan pengamatannya, nampak bahwa tidak ada korelasi positif antara peningkatan keterampilan numerik dan lama waktu yang digunakan saat belajar matematika secara formal di sekolah. Dengan kata lain, seorang anak yang menempuh pendidikan matematika secara formal belum tentu meningkatkan keterampilan numerik mereka. Kemampuan numerik sangat berkaitan dengan disposisi matematika, karena disposisi matematika merupakan salah satu faktor yang ikut menentukan keberhasilan dalam belajar matematika. Seorang siswa yang memiliki disposisi tinggi akan lebih gigih dan ulet dalam menghadapi masalah matematika yang lebih menantang dan akan lebih bertanggung jawab terhadap belajar mereka sendiri serta selalu mengembangkan kebiasaan baik di matematika. Hal ini sesuai dengan pendapat Katz (1993 : 2) yang menyatakan bahwa disposisi matematika berkaitan dengan bagaimana siswa menyelesaikan masalah matematika, apakah mereka menyelesaikannya dengan penuh rasa percaya diri, tekun, berminat, dan berpikir fleksibel untuk menemukan berbagai alternatif penyelesaian masalah.

Disposisi matematika adalah keinginan, kesadaran, dan dedikasi yang kuat pada diri siswa untuk belajar matematika dan melaksanakan berbagai kegiatan matematika. Disposisi matematika siswa dikatakan baik jika siswa tersebut menyukai masalah-masalah yang merupakan tantangan serta melibatkan dirinya secara langsung dalam menemukan/menyelesaikan masalah. Selain itu siswa merasakan dirinya mengalami proses belajar saat menyelesaikan tantangan tersebut. Dalam proses ini siswa merasakan munculnya kepercayaan diri, pengharapan dan kesadaran untuk melihat kembali hasil berpikirnya. Berdasarkan uraian di atas maka penelitian ini dilakukan untuk menyelidiki "Kemampuan Numeik Siswa Ditinjau dari Perbedaan Jenis Kelamin dan Disposisi Matematika SMP Pesisir Kota Kendari. 


\section{METODE PENELITIAN}

Jenis penelitian ini adalah deskriptif eksploratif dengan menggunakan ex post fakto. Tempat penelitiannya adalah di SMP Negeri 6 Kendari pada tahun ajaran 2016/2017. Pengambilan data dari penelitian dilaksanakan pada tanggal 25 Februari 2017 sampai dengan 27 Februari 2017. Adapun populasi penelitian ini dapat di lihat pada Tabel 1.

Tabel 1. Distribusi populasi Siswa Kelas VIII SMPN 6 Kendari

\begin{tabular}{ccccc}
\hline No & Kelas & Jumlah Siswa & Siswa Laki-Laki & Siswa Perempuan \\
\hline 1 & VIII $_{\mathrm{A}}$ & 26 & 14 & 12 \\
2 & VIII $_{\mathrm{B}}$ & 25 & 13 & 12 \\
3 & VIII $_{\mathrm{C}}$ & 24 & 13 & 11 \\
4 & VIII $_{\mathrm{D}}$ & 22 & 11 & 11 \\
5 & VIII $_{\mathrm{E}}$ & 23 & 13 & 10 \\
6 & VIII $_{\mathrm{F}}$ & 24 & 13 & 11 \\
7 & VIII $_{\mathrm{G}}$ & 24 & 16 & 75 \\
Jumlah Populasi & 168 & 93 & \\
\hline
\end{tabular}

Tabel 2. Kisi-Kisi Instrument Tes Kemampuan Numerik

\begin{tabular}{|c|c|c|c|c|}
\hline No & Jenis Soal & Indikator & Nomor Soal & Jumlah \\
\hline \multirow[t]{10}{*}{1} & \multirow{10}{*}{$\begin{array}{l}\text { Hitung - } \\
\text { menghitung }\end{array}$} & Perpangkatan & 1,2 & 2 \\
\hline & & Operasi Pecahan Campuran & $3,7,8$ & 3 \\
\hline & & Operasi bilangan Campuran & 4,14 & 2 \\
\hline & & Operasi Bilangan Bulat & $5,6,13$ & 3 \\
\hline & & Operasi Hitung Aljabar & 9 & 1 \\
\hline & & Operasi Akar Kuadrat & $10,11,12$ & 3 \\
\hline & & Satuan Waktu & 15 & 1 \\
\hline & & Ukuran Panjang & 16,17 & 2 \\
\hline & & Pecahan persen & 18,19 & 2 \\
\hline & & Perbandingan & 20,21 & 2 \\
\hline \multirow[t]{7}{*}{2} & Komparasi & SPLDV & 22 & 1 \\
\hline & \multirow[t]{6}{*}{ Kuantitatif } & Bangun Datar & 23,27 & 2 \\
\hline & & Satuan Ukuran Waktu & 24 & 1 \\
\hline & & Perbandingan & 25 & 1 \\
\hline & & Pecahan Persen & 26,29 & 2 \\
\hline & & Operasi Bilangan Bulat & 28,30 & 2 \\
\hline & & FPB & 31 & 1 \\
\hline \multirow[t]{9}{*}{3} & \multirow{9}{*}{$\begin{array}{l}\text { Penerapan } \\
\text { Konsep } \\
\text { Matematika }\end{array}$} & KPK & 32 & 1 \\
\hline & & Satuan Ukuran Liter & 33 & 1 \\
\hline & & Operasi Bilangan Bulat & 34 & 1 \\
\hline & & Jarak dan Kecepatan & 35 & 1 \\
\hline & & Satuan ukuran Jarak & 36 & 1 \\
\hline & & Aritmatika Sosial & 37 & 1 \\
\hline & & Operasi Campuran & 28,39 & 2 \\
\hline & & Bangun Datar & 40 & 1 \\
\hline & & Jumlah & & 40 \\
\hline
\end{tabular}


Tabel 3. Alternatif kisi-kisi disposisi matematika

\begin{tabular}{|c|c|c|c|c|}
\hline \multirow{2}{*}{ No } & \multirow{2}{*}{ Indikator } & \multicolumn{2}{|c|}{ Sifat Pertanyaan } & \multirow{2}{*}{ Jumlah } \\
\hline & & $\mathbf{P}(+)$ & $\mathbf{N}(-)$ & \\
\hline 1. & $\begin{array}{l}\text { Kepercayaan diri dalam menyelesaikan } \\
\text { masalah matematika, mengkomunikasikan ide- } \\
\text { ide, dan memberikan alasan ( } \mathrm{A})\end{array}$ & $1,6,8,9$ & $\begin{array}{c}2,3,4,5 \\
7\end{array}$ & 9 \\
\hline 2. & $\begin{array}{l}\text { Fleksibilitas dalam mengeksplorasikan ide-ide } \\
\text { matematika dan mencoba berbagai alternatif } \\
\text { untuk memecahkan masalah ( B) }\end{array}$ & $\begin{array}{c}10,12 \\
13\end{array}$ & 11 & 4 \\
\hline 3. & $\begin{array}{l}\text { Bertekad kuat untuk menyelesaikan tugas-tugas } \\
\text { matematika (C) }\end{array}$ & $\begin{array}{c}14,16 \\
18\end{array}$ & 15,17 & 5 \\
\hline 4. & $\begin{array}{l}\text { Ketertarikan, keingintahuan, dan kemampuan } \\
\text { untuk menemukan dalam mengerjakan } \\
\text { matematika (D) }\end{array}$ & $\begin{array}{c}21,22 \\
24\end{array}$ & $\begin{array}{l}19,20 \\
23,25\end{array}$ & 7 \\
\hline 5. & $\begin{array}{l}\text { Kecenderungan untuk memonitor dan } \\
\text { merefleksi proses berpikir dan kinerja diri } \\
\text { sendiri ( E) }\end{array}$ & $\begin{array}{l}26,27 \\
29,30 \\
32\end{array}$ & 28,31 & 7 \\
\hline 6. & $\begin{array}{l}\text { Menilai aplikasi matematika dalam bidang lain } \\
\text { dan dalam kehidupan sehari-hari ( F) }\end{array}$ & $\begin{array}{c}33,35 \\
36\end{array}$ & 34,37 & 5 \\
\hline \multirow[t]{2}{*}{7.} & $\begin{array}{l}\text { Penghargaan (apprectiation) peran matematika } \\
\text { dalam budaya dan nilainnya, baik matematika } \\
\text { sebagai alat, maupun matematika sebagai } \\
\text { bahasa }(G)\end{array}$ & $\begin{array}{l}38,39 \\
40\end{array}$ & - & 3 \\
\hline & Jumlah & 25 & 15 & 40 \\
\hline
\end{tabular}

Secara apriori skala yang berarah positif akan mempunyai skor 4 (SS), 3 (S), 2 (TS), dan 1 (STS), dan skala yang berarah negatif mempunyai skor sebaliknya. Dalam penelitian ini menggunakan pemberian skor secara apriori. Dengan kriteia pemberian skor sesuai dengan Tabel berikut.

Tabel 4. Kriteria Pemberian Skor

\begin{tabular}{ccccc}
\hline $\begin{array}{c}\text { Sifat } \\
\text { Peryataan }\end{array}$ & $\begin{array}{c}\text { Sangat Setuju } \\
\text { (SS), }\end{array}$ & $\begin{array}{c}\text { Kriteria Pemberian Skor } \\
\text { Setuju }\end{array}$ & $\begin{array}{c}\text { Tidak Setuju } \\
\text { (TS) }\end{array}$ & $\begin{array}{c}\text { Sangat Tidak Setuju } \\
\text { (STS) }\end{array}$ \\
\hline Positif & 4 & 3 & 2 & 1 \\
Negatif & 1 & 2 & 3 & 4 \\
\hline
\end{tabular}

Teknik pengumpulan data yang digunakan pada penelitian ini adalah:

1. Observasi

Observasi dalam penelitian ini dilaksanakan di kelas VIII SMP Negeri 6 Kendari. Tujuan peneliti melakukan observasi untuk mengetahui secara langsung data pribadi siswa yaitu siswa laki-laki dan siswa perempuan.

2. Metode Angket
Data ini diperoleh dengan memberikan angket secara langsung kepada siswa yang dijadikan sampel penelitian ini. Setelah angket diisi, jawaban masing-masing responden diperiksa kemudian diberikan skor sesuai jawaban responden. Skor total yang diperoleh dikonversi dalam bentuk nilai skala 0 sampai 100 dengan menggunakan rumus sebagai berikut: 


$$
X=\frac{X_{p}}{X_{\max }} \times 100 \%
$$

Tes dalam penelitian ini diambil dari tes potensial akademik (TPA) sebanyak 40 butir soal. Analisis yang digunakan untuk mengembangkan keadaan sampel dalam bentuk, rata-rata $(\bar{X})$, standar deviasi $(\mathrm{S})$, median, persentase $(\%)$, nilai maksimum $\left(\mathrm{X}_{\max }\right)$, nilai minimum $\left(\mathrm{X}_{\min }\right)$ dan grafik/tabel/diagram. Untuk mengetahui persentase kemampuan numerik siswa digunakan rumus sebagai berikut:

$$
X=\frac{S S}{S T} \times 100 \%
$$

Keterangan:

$X=$ persentase kemampuan numerik siswa

$S S=$ skor siswa

$S T=$ skor total

Nilai persentase siswa tersebut merupakan data dari penelitian ini. Apabila siswa memperoleh skor $(X \geq 80)$

\section{HASIL PENELITIAN}

Hasil statistik deskriptif Kemampuan Numerik Siswa Kelas VIII maka siswa dikatakan memiliki kemampuan numerik yang "tinggi", apabila siswa memperoleh skor ( $80>X \geq$ 60) siswa dikatakan memiliki kemampuan numerik "sedang", dan apabila siswa memperoleh skor $(X<60)$ maka siswa dikatakan memiliki kemampuan numerik "rendah". Analisis deskriptif dimaksudkan untuk mendeskripsikan atau menggambarkan disposisi matematika siswa dalam bentuk rata-rata, median, modus, dan standar deviasi. Analisis deskriptif disposisi matematika siswa digunakan pedoman sebagai berikut:

$$
\begin{gathered}
X \geq \bar{X}+0,5 S D ; \text { Tinggi } \\
\bar{X}-0,5 \mathrm{SD}<X \leq \bar{X}+0,5 S D ; \text { Sedang } \\
\mathrm{X}<\bar{X}-0,5 S D ; \text { Rendah }
\end{gathered}
$$

SMP Negeri 6 Kendari dapat dilihat pada Tabel 5 berikut

Tabel 5. Statistik Deskriptif Kemampuan Numerik siswa Kelas VIII SMP 6 Kendari.

\begin{tabular}{cccccc}
\hline Jenis Kelamin & Rata-rata & Min & Max & Median & Standar Deviasi \\
\hline L & 85.26 & 37.5 & 100 & 87.5 & 13.55 \\
P & 89 & 60 & 100 & 92.5 & 11.35 \\
L \& P & 86.93 & 37.5 & 100 & 87.5 & 12.7 \\
\hline
\end{tabular}

Rata-rata nilai kemampuan numerik siswa laki-laki dan siswa perempuan sebesar 86.93, yang memiliki nilai ratarata kemampuan numerik siswa perempuan lebih tinggi daripada nilai kemampuan numeik siswa laki-laki. Berikut Tabel 6 kemampuan numerik siswa berdasarkan kategori.

Tabel 6. Kemampuan Numerik Siswa Berdasarkan Kategorinya

\begin{tabular}{ccccc} 
Kategori & L & P & Total & $\%$ \\
\hline Tinggi & 58 & 58 & 116 & 69.04 \\
Sedang & 34 & 17 & 51 & 30.35 \\
Rendah & 1 & 0 & 1 & 0.59 \\
Total & 93 & 75 & 168 & 100 \\
\hline
\end{tabular}

Kemampuan numerik siswa berdasarkan kategosri tinggi 69,04\%, kategori sedang $30,35 \%$ dan kategori rendah $0,59 \%$. Pengelompokan data kemampuan numerik siswa berdasarkan jenis soal dalam hitung-menghitung, 
komparasi kuantitatif dan penerapan konsep matematika sebagai berikut.

Tabel 1.7. Deskripsi Persentase Data Kemampuan Numerik Siswa Berdasarkan Jenis

Soal

\begin{tabular}{|c|c|c|c|c|c|}
\hline \multicolumn{2}{|c|}{ Kategori } & $\begin{array}{c}\text { Hitung- } \\
\text { menghitung }\end{array}$ & $\begin{array}{l}\text { Komparasi } \\
\text { Kuantitatif }\end{array}$ & $\begin{array}{c}\text { Penerapan Konsep } \\
\text { Matematika }\end{array}$ & $\mathbf{L} \& \mathbf{P}$ \\
\hline \multirow{2}{*}{ Tinggi } & $\mathrm{L}$ & 48.85 & 49.89 & 48.9 & 49.1 \\
\hline & $\mathrm{P}$ & 55.52 & 53.33 & 51.2 & 53.95 \\
\hline \multirow{2}{*}{ Sedang } & $\mathrm{L}$ & 26.38 & 27.33 & 25.5 & 26.375 \\
\hline & $\mathrm{P}$ & 12.33 & 11.89 & 11.6 & 12.05 \\
\hline \multirow{2}{*}{ Rendah } & $\mathrm{L}$ & 0.38 & 0.44 & 0.3 & 0.375 \\
\hline & $\mathrm{P}$ & 0 & 0 & 0 & 0 \\
\hline \multirow{2}{*}{$\mathrm{L} \& \mathrm{P}$} & $\mathrm{L}$ & 19.82 & 25.89 & 24.9 & 25.8 \\
\hline & $\mathrm{P}$ & 14.49 & 21.74 & 20.93 & 22 \\
\hline \multicolumn{2}{|c|}{ Gab. L \& P } & 17.84 & 23.81 & 22.91 & 23.64 \\
\hline
\end{tabular}

Perbandingan kemampuan numerik siswa berdasarkan jenis soal pada setiap kategori antara siswa laki-laki dan siswa hitung-menghitung sedangkan kemampuan numerik tinggi pada jenis soal komparasi kuantitatif. perempuan rendah pada kemampuan

Tabel 8. Deskriptif Disposisi Matematika Siswa Kelas VIII SMP Negeri 6 Kendari.

\begin{tabular}{cccccc}
\hline JK & Rata-rata & Min & Max & Median & Standar Deviasi \\
\hline L & 69.19 & 55.6 & 86.25 & 67.5 & 6.04 \\
P & 68.05 & 46.8 & 83.75 & 66.25 & 6.61 \\
L \& P & 68.62 & 46.8 & 86.25 & 66.875 & 0.403 \\
\hline
\end{tabular}

Rata-rata nilai disposisi matematikasiswa laki-laki dan siswa perempuan sebesar 68,62 , median 66,875 dan standar deviasi 0,403 yang memilki

nilai minimal 46,8 dan nilai maksimal 86,25. Pengelompokan data kemampuan numerik siwa berdasarkan kategori sebagai berikut.

Tabel 9. Deskripsi Pengelompokan Data Disposisi Matematika Berdasarkan Kategorinya.

\begin{tabular}{ccccc}
\hline Kategori & L & $\mathbf{P}$ & L \& P & \% \\
\hline Tinggi & 36 & 31 & 67 & 39.881 \\
Sedang & 57 & 44 & 101 & 60.119 \\
Rendah & 0 & 0 & 0 & 0 \\
Total & 93 & 75 & 168 & 100 \\
\hline
\end{tabular}

Pengelompokan data disposisi matematika siswa berdasarkan kategori tinggi 39,881\%, disposisi matematika siswa berdasarkan kategori sedang 60,119\% dan disposisi matematika siswa

berdasarkan kategori rendah tidak ada atau nol. Siswa laki-laki yang memiliki kategori tinggi 36 siswa dan siswa perempuan 31, Siswa laki-laki yang memiliki kategori tinggi 57 siswa dan 
siswa perempuan 44, Siswa laki-laki dan siswa perempuan tidak ada ataunol. Deskripsi pengelompokan data disposisi matematika siswa berdasarkan indikator sebagai berikut.

Tabel 10. Deskripsi Pengelompokan Data Disposisi Matematika Siswa Berdasarkan Indikator.

\begin{tabular}{cccccccccc}
\hline \multicolumn{1}{c}{ Kategori } & \multicolumn{7}{c}{ Indikator } \\
& & $\mathbf{A}$ & $\mathbf{B}$ & $\mathbf{C}$ & $\mathbf{D}$ & $\mathbf{E}$ & $\mathbf{F}$ & $\mathbf{G}$ & $\begin{array}{c}\text { Total } \\
\text { Gab. }\end{array}$ \\
\hline \multirow{2}{*}{ Tinggi } & $\mathrm{L}$ & 29.62 & 34.72 & 31.67 & 28.57 & 28.96 & 20.55 & 25.92 & 28.57 \\
& $\mathrm{P}$ & 22.93 & 38.7 & 36.12 & 24.42 & 39.63 & 29.03 & 43.01 & 33.405 \\
Sedang & $\mathrm{L}$ & 15.78 & 14.03 & 18.59 & 11.02 & 16.29 & 18.245 & 20.46 & 16.34 \\
& $\mathrm{P}$ & 11.11 & 12.5 & 22.72 & 12.01 & 19.15 & 15 & 34.09 & 18.08 \\
Rendah & $\mathrm{L}$ & 0 & 0 & 0 & 0 & 0 & 0 & 0 & 0 \\
& $\mathrm{P}$ & 0 & 0 & 0 & 0 & 0 & 0 & 0 & 0 \\
Total & $\mathrm{L}$ & 15.13 & 16.25 & 16.75 & 13.19 & 15.08 & 12.93 & 15.46 & 14.97 \\
Gab. & $\mathrm{P}$ & 11.34 & 17.06 & 19.61 & 12.14 & 19.59 & 14.67 & 25.7 & 17.16 \\
\multicolumn{1}{c}{ L \& P } & & 13.24 & 16.65 & 18.18 & 12.67 & 17.33 & 13.8 & 20.58 & 16.06 \\
\hline
\end{tabular}

Rata-rata disposisi matematika siswa laki-laki dan perempuan berbedabeda yaitu siswa lemah pada ketertarikan, keingintahuan dan kemampuan untuk menemukan dalam mengerjakan matematika dengan disposisi matematika jenis kelamin siswa laki-laki lebih tinggi daripada dispsisi matematika siswa perempuan.

Kemampuan numerik sangat berkaitan dengan disposisi matematika, karena disposisi matematika merupakan salah satu faktor yang ikut menentukan keberhasilan dalam belajar matematika. Siswa yang memiliki disposisi matematika tinggi akan lebih gigih dan ulet dalam menghadapi masalah matematika yang lebih menantang dan akan lebih bertanggung jawab terhadap belajar mereka sendiri serta selalu mengembangkan kebiasaan baik di matematika. Keterkaitan kemampuan numerik siswa dan disposisi matematika dapat disajikan pada Tabel 11.

Tabel 11. Keterkaitan Kemampuan Numerik Siswa Dan Disposisi Matematika Siswa.

\begin{tabular}{lccccccc}
\hline \multicolumn{1}{c}{ DM } & \multicolumn{6}{c}{ Tinggi } & \multicolumn{2}{c}{ Sedang } & \multicolumn{2}{c}{ Rendah } & \multirow{2}{*}{ L \& P } \\
& L & $\mathbf{P}$ & L & $\mathbf{P}$ & $\mathbf{L}$ & $\mathbf{P}$ & \\
\hline Tinggi & 24 & 23 & 12 & 8 & 0 & 0 & 67 \\
Sedang & 34 & 35 & 22 & 9 & 1 & 0 & 101 \\
Rendah & 0 & 0 & 0 & 0 & 0 & 0 & 0 \\
Total Gab. & 58 & 58 & 34 & 17 & 1 & 0 & 168 \\
\hline
\end{tabular}

Keterkaitan kemampuan numerik siswa dan dan disposisi matematika lebih banyak pada kategori tinggi sedangkan pada kategori rendah siswa perempuan tidak ada atau nol. Banyaknya siswa yang memiliki kemampuan numerik tinggi dan disposisi tinggi 67 siswa, banyaknya siswa yang memiliki kemampuan numerik sedang dan disposisi sedang 101 siswa dan Banyaknya siswa yang memiliki 
kemampuan numerik rendah dan disposisi rendah 0 siswa.

\section{PEMBAHASAN}

Kemampuan numerik siswa laki-laki dan perempuan pada kategori tinggi adalah sama. Kemampuan numerik pada kategori sedang sangat berbeda yaitu pada siswa laki-laki sebanyak 34 siswa dan pada siswa perempuan sebanyak 17 siswa. Kemampuan numerik yang berkategori rendah hanya 1 siswa yaitu siswa yang berjenis kelamin laki-laki.

Rata-rata kemampuan numerik siswa laki-laki berdasarkan jenis soal hitungmenghitung sebesar 19,82 dan rata-rata kemampuan numerik siswa perempuan jenis soal hitung-menghitung sebesar 14,49 maka nilai rata-rata kemampuan numerik siswa laki-laki dan siswa perempuan untuk jenis soal hitungmenghitung adalah 17,84. Adapun ratarata kemampuan numerik siswa laki-laki berdasarkan jenis soal komparasi kuantitatif sebesar 25,89 dan rata-rata kemampuan numerik siswa perempuan jenis soal komparasi kuantitatif sebesar 21,74 maka nilai rata-rata kemampuan numerik siswa laki-laki dan perempuan adalah 23,81. Sedangkan rata-rata kemampuan numerik siswa laki-laki berdasarkan jenis soal penerapan konsep matematika sebesar 24,9 dan rata-rata kemampuan numerik siswa perempuan jenis soal penerapaan konsep matemaatika sebesar 20,95 maka nilai rata-rata kemampuan numerik siswa laki-laki dan siswa perempuan adalah 22,91. Dari uraian tersebut maka dapat disimpulkan bahwa siswa lemah pada penerapan konsep matematika. Dari uraian tersebut maka dapat disimpulkan bahwa siswa lemah pada penerapan konsep matematika. Perbandingan kemampuan numerik siswa berdasarkan jenis soal pada setiap kategori antara siswa laki-laki dan siswa perempuan rendah pada kemampuan hitung-menghitung, tinggi pada kemampuan komparasi kuantitatif dan sedang pada penerapan konsep matematika.

Analisis deskripsi dimaksudkan pada disposisi matematika untuk memberikan gambaran tentang karasteristik penelitian yang menjadi tujuan peneliti. Berdasarkan Tabel 1.8. Rata-rata nilai disposisi matematika siswa laki-laki sebesar 69,19, median 67,5 dan standar deviasi 6,04 yang memiliki nilai minimal 55,6 dan nilai maksimal 86.25 sedangkan rata-rata nilai disposisi matematika siswa perempuan sebesar 68,05, median 66,25 dan standar deviasi 6,61 yang memiliki nilai minimal 46,8 dan nilai maksimal 83,75. Oleh karena itu, rata-rata nilai disposisi matematika siswa laki-laki dan siswa perempuan sebesar 68,62, median 66,875 dan standar deviasi 0,403 yang memiliki nilai minimal 46,8 dan nilai maksimal 86,25 . Perbandingan disposisi matematika siswa laki-laki dan siswa perempuan memiliki kesamaan dan perbedaan, namun nampak jelas bahwa pada siswa kelas VIII SMP Negeri 6 Kendari disposisi matematika siswa laki-laki lebih baik daripada siswa perempuan.

Pengelompokan data disposisi matematika siswa berdasarkan kategori tinggi sebanyak 67 siswa atau 39,881\% dimana banyaknya siswa laki-laki yang berkategori tinggi 36 siswa dan banyaknya siswa perempuan yang berkategori tinggi sebanyak 31 siswa. Pengelompokan data disposisi matematika siswa berdasarkan kategori sedang sebanyak 101 siswa atau $60,119 \%$ dimana banyaknya siswa lakilaki yang berkategori sedang 57 siswa dan banyaknya siswa perempuan yang berkategori sedang 44 siswa. Pengelompokan data disposisi matematika siswa laki-laki dan siswa perempuan tidak ada atau nol.

Disposisi matematika siswa laki-laki pada indikator kepercayaan diri dalam 
menyelesaikan masalah matematika, mengkomunikasikan ide-ide, dan memberikan alasan sebanyak 29,62\% sedangkan siswa perempuan sebanyak 22,93\%. Disposisi matematika siswa lakilaki dalam kategori sedang sebanyak $15,78 \%$ sedangkan siswa perempuan $11,11 \%$. Disposisi matematika siswa lakilaki dan perempuan dalam kategori rendah tidak ada atau nol. Adapun disposisi matematika siswa laki-laki pada indikator fleksibilitas dalam mengeksplorasikan ideide matematika dan mencoba berbagai alternatif untuk memecahkan masalah sebanyak $34,72 \%$ sedangkan siswa perempuan sebanyak $38,7 \%$. Disposisi matematika siswa laki-laki dalam kategori sedang sebanyak $14,03 \%$ sedangkan siswa perempuan sebanyak 12,5\%. Disposisi matematika siswa laki-laki dan perempuan dalam kategori rendah tidak ada atau nol. Disposisi matematika siswa laki-laki pada indikator bertekad kuat untuk menyelesaikan tugas-tugas matematika sebanyak $31,67 \%$ sedangkan siswa perempuan sebanyak 36,12\%. Disposisi matematika siswa laki-laki dalam kategori sedang sebanyak $18,59 \%$ sedangkan siswa perempuan sebanyak 22,72\%. Disposisi matematika siswa laki-laki dan perempuan dalam kategori rendah tidak ada atau nol.

Sedangkan disposisi matematika siswa laki-laki pada indikator ketertarikan, keingintahuan, dan kemampuan untuk menemukan dalam mengerjakan matematika sebanyak $28,57 \%$ sedangkan siswa perempuan sebanyak $24,42 \%$. Disposisi matematika siswa laki-laki dalam kategori sedang sebanyak 11,02\% sedangkan siswa perempuan sebanyak 12,01\%. Disposisi matematika siswa lakilaki dan perempuan dalam kategori rendah tidak ada atau nol. Adapun disposisi matematika siswa laki-laki pada indikator kecenderungan untuk memonitor dan merefleksi proses berpikir dan kinerja diri sendiri sebanyak $28,96 \%$ sedangkan siswa perempuan sebanyak 39,63\%. Disposisi matematika siswa laki-laki dalam kategori sedang sebanyak $16,29 \%$ sedangkan siswa perempuan sebanyak $19,15 \%$. Disposisi matematika siswa laki-laki dan perempuan dalam kategori rendah tidak ada atau nol.

Disposisi matematika siswa laki-laki pada indikator menilai aplikasi dalam bidang lain dan dalam kehidupan seharihari sebanyak 20,55\% sedangkan siswa perempuan sebanyak 29,03\%. Disposisi matematika siswa laki-laki dalam kategori sedang sebanyak $18,245 \%$ sedangkan siswa perempuan sebanyak $15 \%$. Disposisi matematika siswa laki-laki dan perempuan dalam kategori rendah tidak ada atau nol. Disposisi matematika siswa laki-laki pada indikator penghargaan peran matematika dalam budaya dan nilainya, baik matematika sebagai alat maupun matemaika sebagai bahasa sebanyak $25,92 \%$ sedangkan siswa perempuan sebanyak 43,01\%. Rata-rata disposisi matematika siswa laki-laki dalam kategori sedang sebesar 20,46 sedangkan rata-rata pada siswa perempuan sebesar 34,09\%. Disposisi matematika siswa laki-laki dan perempuan dalam kategori rendah tidak ada.

Rata-rata nilai dispsosisi matematika siswa laki-laki dan siswa perempuan berdasarkan indikator berbeda-beda. Indikator kepercayaan diri dalam menyelesaikan masalah matematika, mengkomunikasikan ide-ide dan memberikan alasan disposisi matematika siswa laki-laki sebesar 15,13 dan rata-rata disposisi matematika siswa perempuan sebesar 11,34 maka rata-rata disposisi matematika siswa laki-laki dan siwa perempuan sebesar 13,24. Indikator fleksibilitas dalam mengeksplorasikan ideide matematika dan mencoba berbagai alternatif untuk memecahkan masalah disposisi matematika siswa laki-laki memilki rata-rata sebesar 16,25 dan ratarata disposisi matematika siswa perempuan sebesar 17,06 maka rata-rata disposisi matematika siswa laki-laki dan siwa perempuan sebesar 16,65. Indikator bertekad kuat untuk menyelesaikan tugas- 
tugas matematika disposisi matematika siswa laki-laki memiliki rata-rata sebesar 16,75 dan rata-rata disposisi matematika siswa perempuan sebesar 17,19,61 maka rata-rata disposisi matematika siswa lakilaki dan siwa perempuan sebesar 18,18.

Indikator ketertarikan, keingintahuan dan kemampuan untuk menemukan dalam mengerjakan matematika disposisi matematika siswa laki-laki memiliki ratarata sebesar 13,19 dan rata-rata disposisi matematika siswa perempuan sebesar 12,14 maka rata-rata disposisi matematika siswa laki-laki dan siwa perempuan sebesar 12,67. Indikator kecenderungan untuk memonitor dan merefleksi proses berpikir dan kinerja diri sendiri disposisi matematika siswa laki-laki memiliki ratarata sebesar 15,08 dan rata-rata disposisi matematika siswa perempuan sebesar 19,59 maka rata-rata disposisi matematika siswa laki-laki dan siwa perempuan sebesar 17,33. Indikator menilai aplikasi dalam bidang lain dan dalam kehidupan sehari-hari disposisi matematika siswa laki-laki memiliki rata-rata sebesar 12,93 dan rata-rata disposisi matematika siswa perempuan sebesar 11,67 maka rata-rata disposisi matematika siswa laki-laki dan siwa perempuan sebesar 13,8. Indikator penghargaan peran matematika dalam budaya dan nilainya baik matematika sebagai alat, maupun matematika sebagai bahasa disposisi matematika siswa lakilaki memiliki rata-rata sebesar 15,46 dan rata-rata disposisi matematika siswa perempuan sebesar 25,7 maka rata-rata disposisi matematika siswa laki-laki dan siwa perempuan sebesar 20,58.

\section{KESIMPULAN DAN SARAN}

Kesimpulan dari penelitian ini yaitu

1. Kemampuan numerik siswa laki-laki dan perempuan sudah baik tetapi dari ketiga jenis soal siswa masih lemah pada hitung-menghitung.

2. Kemampuan numerik siswa dengan disposisi matematika tinggi sangat baik.
Berdasarkan uraian tersebut, rata-rata disposisi matematika siswa laki-laki sebesar 14,97 dan rata-rata disposisi matematika siswa perempuan sebesar 17,16 maka rata-rata disposisi matematika siswa laki-laki dan siwa perempuan sebesar 16,08.

Keterkaitan kemampuan numerik siswa dan disposisi matematika nampak jelas bahwa kemampuan numerik siswa laki-laki kategori tinggi dan disposisi matematika siswa laki-laki kategori tinggi sebanyak 24 siswa, kemampuan numerik sedang dan disposisi tinggi 12 siswa sedangkan kemampuan numerik rendah dan disposisi matematika tinggi tidak ada atau nol. Kemampuan numerik siswa lakilaki kategori tinggi dan disposisi matematika sedang sebanyak 34 siswa, sedangkan kemampuan numerik sedang dan disposisi matematika sedang sebanyak 22 siswa serta kemampuan numerik siswa kategori rendah dan disposisi matematika sedang hanya 1 siswa laki-laki.

Adapun kemampuan numerik perempuan kategori tinggi dan disposisi matematika siswa laki-laki kategori tinggi sebanyak 23 siswa, kemampuan numerik sedang dan disposisi tinggi 8 siswa sedangkan kemampuan numerik rendah dan disposisi matematika tinggi tidak ada atau nol. Kemampuan numerik perempuan kategori tinggi dan disposisi matematika sedang sebanyak 35 siswa, sedangkan kemampuan numerik sedang dan disposisi matematika sedang sebanyak 9 siswa serta kemampuan numerik siswa kategori rendah dan disposisi matematika siswa berkategori sedang tidak ada.

3. Kemampuan numerik siswa dengan disposisi matematika sedang sudah baik

4. Kemampuan numerik siswa laki-laki kategori rendah dan disposisi matematika siswa laki-laki kategori rendah hanya 1 siswa

5. Disposisi matematika siswa laki-laki dan perempuan lemah pada 
ketertarikan, keingintahuan, dan kemampuan untuk menemukan dalam mengerjakan matematika.

Berdasarkan pembahasan dan kesimpulan hasil penelitian, maka penulis menyarankan bahwa perlu dilakukan

\section{DAFTAR PUSTAKA}

Denzim, N. 1994. Entering the Field of Qualitative Research. CA : Sage Publication.

Depdiknas. 2002. Pendekatan contekstual Taching and Learning (CTL). Jakarta: Depdiknas.

Djaali \& Mulyono. 2004. Pengukuran Dalam Bidang Pendidikan. Jakarta: Universitas Negeri.

Katz, L. G. 1993. Dispostions as Educational Goals.[Online]. Tersedia: http://www.edpsycinteractive.org/fil es/edoutcomes.html [12 September 2017].

Mulyasa, E. 2006. Kurikulum Tingkat Satuan Pendidikan. Bandung: PT Remaja Rosdakarya

Nurhaja. 2012. Pengaruh Disposisi Matematika dan Dukungan Sosial Terhadap Prestasi Belajar Matematika Siswa SMA Negeri 7 dan SMA Negeri 9 Kendari. Skripsi. FKIP UHO.

O'donoghue, A. 2007. Pigging as FlowAssurance Solution. Pipeline Research Limited, Glasgow.

Sujana, C. 2008. Cara Mengembangkan Komponen Kecerdasan. Yogyakarta: PT Indeks.

Sunarto. 2008. Perkembangan Peserta Didik. Jakarta: Rineka Cipta.

Suparlan \& Juhariah. 2009. Pengaruh Minat dan Kecerdasan Numerik Terhadap Prestasi Belajar Matematika siswa. pendekatan kepada siswa-siswa yang bermasalah disekolah agar mereka dapat lebih tertarik pada pelajaran matematika guna untuk meningkatkan disposisi matematika siswa.

Tim Litbang Psik-Akademik Salemba. 2015. The King Cerdik Nalar TPA. Forum Edukasi. Yogyakarta. 